\title{
Needs Analysis and Course Design; A Framework for Designing Exam Courses
}

\author{
Reza Eshtehardi \\ The British Council Malaysia, Kuala Lumpur, Malaysia \\ E-mail: eshtehardi8@gmail.com
}

Received: 12-04-2017

Published: 01-11-2017
Accepted: 19-06-2017

doi:10.7575/aiac.ijalel.v.6n.6p.274
Advance Access Published: September 2017

URL: http://dx.doi.org/10.7575/aiac.ijalel.v.6n.6p.274

\begin{abstract}
This paper introduces a framework for designing exam courses and highlights the importance of needs analysis in designing exam courses. The main objectives of this paper are to highlight the key role of needs analysis in designing exam courses, to offer a framework for designing exam courses, to show the language needs of different students for IELTS (International English Language Testing System) exam, to offer an analysis of those needs and to explain how they will be taken into account for the design of the course. First, I will concentrate on some distinguishing features in exam classes, which make them different from general English classes. Secondly, I will introduce a framework for needs analysis and diagnostic testing and highlight the importance of needs analysis for the design of syllabus and language courses. Thirdly, I will describe significant features of syllabus design, course assessment, and evaluation procedures.
\end{abstract}

Keywords: backwash effects, exam classes, receptive skills, ND (Needs Analysis), DT (Diagnostic Testing), ESP (English for Specific Purposes), IELTS (International English Language Testing System)

\section{Introduction}

The term 'analysis of needs' first introduced and used by Michael West in India in the 1920s (Howatt, 1984:245; Tickoo, 1988). It was developed and emphasized in ESP (English for Specific Purposes) and it is argued that it is not possible to analyze the needs of general English learners. Hutchinson and Walters (1987) describe need analysis as the most prominent feature of English for Specific Purposes course design. Needs analysis is actually the starting point for a course design. It is a necessary part of a curriculum development and is required in the early stages of developing a syllabus. Thus, the information gathered from a need analysis can be used to highlight the program objectives and to select relevant material for the syllabus. A successful course begins when both teachers and students are brought together through the course syllabus. An effective course design conveys information about expectations. It functions as a contract between teacher and students. Entering university is a major goal for many students; therefore they need to improve their language proficiency in order to pass a standard language exam like IELTS. There are students who fail to achieve their desired results in standard examinations even after attending exam preparation classes. This is mainly because some exam courses are not fully designed based on students' needs, wants, and expectations. This study introduces a standard framework for syllabus/course designers based on students' actual needs for academic contexts.

\subsection{Exam and General English Classes}

There are some distinctive features in exam classes that make them different from general English classes:

1.1.1 Clear objectives: Nauton \& Hughes (1997) note that an exam course has clear goals. Accordingly, the teacher's lesson plans will also have specific objectives. They also believe that an exam course places greater demands on the learners but, at the end, the successful ones receive a qualification.

1.1.2 Common objectives: Nauton \& Hughes (1997) also note that on an exam course, all students have a common objective to follow, but on a general English course, there are various purposes such as students who need English for other purposes like business or students who have been sent to take the course.

1.1.3 High stakes: Exam classes are at high stakes. This is another distinctive feature of exam classes and may have different effects on a course such as harmful/beneficial backwash.

A course planner can create harmful backwash by being too worried about the test and therefore creates no balance between testing and teaching. Exams students and teachers need to have a clear understanding of the course. Teachers and course designer must be aware that all objectives and planning in an exam course must be based on needs, wants and weaknesses of students.

\subsection{Backwash Effect}

Testing has a great influence on teaching and learning. What is assessed becomes what is valued, which becomes what is taught (McEwan 1995:42). Prodmorou (1995) defines backwash as the direct or indirect effect of examinations on teaching methods. Hughes (1989) categorizes backwash into harmful and beneficial and believes that if the course is planned purely "to the test" and does not take into account the linguistic needs of the learners, then there is likely to be 
harmful backwash. In order to avoid harmful backwash, there must be a logical balance between testing and teaching. The teacher and course designer must consider the importance of each. Lessons should be interesting and useful to prepare students for a test. Nauton \& Hughes (1997) agree that students on exam courses need to improve their general language proficiency as well as exams skills in order to pass the exam and to use English in their real-life situations. We should avoid a situation whereby students are proficient in exam skills but lack the essential language skills outside the exam environment. In order to keep the balance between teaching and testing, a course designer needs to design lessons that encourage students to learn rather than to test.

\subsection{Exam Class Students}

Nauton \& Hughes (1997) believe that exam students have a particular sense of purpose, which we do not usually find in general classes. They also have different expectations of the course and teacher. They are often spending a substantial amount of money in order to benefit from teacher's expertise. As Burgess and Head (2005) reflect they expect their teacher to be completely familiar with the format of the exam and help them be familiar too, provide useful tips on how to tackle each part, help them develop their language skills and provide feedback on homework. There are also various reasons that have negative effects on students such as anxiety, burnout factor, class time, student age etc. Some exam classes are quite boring for students. In order to avoid these negative factors, a course planner should prepare interesting tasks, select topics of interest and plan discussion activities even when the objective of the lesson is to develop receptive skills.

\subsection{Motivation}

Motivation is a key factor in exam classes. Students tend to be highly motivated comparing with general classes students. The level of motivation among students tends to be quite high at the start of a course. Burgess (2005) notes that most students start with a strong feeling that they can succeed, and teachers need to support them by understanding that belief, especially when they are becoming anxious, but in my experience, this needs to be qualified, as I have seen many students who feel opposite. Harmer (2007) believes that a variety of factors can create motivation for students. External and internal factors create extrinsic, intrinsic and instrumental motivations. Many exam learners are extrinsically motivated, that is there is an external factor - like passing a university entrance exam - which motivates them. Intrinsic motivation is created by what happens inside the classroom - like being able to communicate well in class. It can also be instrumental in that the exam will help them carry out tasks in English - like doing assignments at university. However, exam students are not always highly motivated due to various reasons, for instance, they could be purely extrinsically motivated or sent to class by parents or they could become demotivated by poor results. Teachers have great roles in class to sustain motivation throughout the course. This can be done as Harmer (2007) mentions by different techniques and planning such as giving students more agency in class, caring about individual students' needs and planning more motivating tasks.

\subsection{Student Autonomy}

Student autonomy plays an important role in exam courses. Exam students should develop a wide variety of skills and strategies in order to achieve successful results. May (1996) defines student autonomy as activities to raise learners' awareness of exam questions and make students more independent in order to tackle exam appropriately. Oxford (1990) notes that most of these skills and strategies refer to meta-cognitive strategies: they include exams training which involves learners becoming familiar with the content of the exam and strategies training which involves helping learners develop their competence in language skills such as thinking about the text's topic before reading it. An exam teacher, therefore, should consider students' autonomy by planning more learner training tasks such as skimming, scanning and dictionary skills activities.

Therefore, an exam class course designer is supposed to design a course...

- based on learners' needs, wants and weaknesses,

- to minimize negative backwash,

- to sustain interest and motivation,

- with clear and specific objectives,

- to reduce students anxiety and burnout effect,

- to focus on strategies and encourage self-study.

\section{Needs Analysis}

\subsection{Learners' Profile}

I randomly selected a class of four pre-intermediate students for this research. Their Listening and Reading scores were below 4 but their Speaking and Writing were 5 to 5.5 in an academic mock IELTS placement test, so clearly they need to improve their Reading and Listening scores to 5.5 in order to enter university.

\begin{tabular}{lllll}
\hline & S 1 & S 2 & S 3 & S 4 \\
\hline Nationality & Chinese & Chinese & Malaysian & Yemeni \\
\hline Age & 21 & 22 & 25 & 23 \\
\hline Gender & Female & Female & Male & Male \\
\hline Class & Mon. \& Wed. & 4 hours & The British Council Malaysia & \\
\hline
\end{tabular}




\subsection{Needs Analysis (NA) and Diagnostic Testing (DT)}

Graves (2000) notes that needs analysis is a systematic and ongoing process of gathering information about students' needs and interpreting the information in order to have an effective course to meet the needs. Nunan (1988) categorizes information about students in two groups: objective and subjective. Objective information includes facts about who the students are, their language abilities and why they need the language. Subjective information includes the attitudes and expectations that students have about the course. I have collated both subjective and objective data, as I believe both of them are necessary in order to have a clear picture of students' needs.

2.2.1 Needs Analysis (NA) Questionnaire: Suggested by Hutchinson and Waters (1987), I have used a variety of methods in order to have a better understanding of the students' actual needs. An NA questionnaire is designed to collate subjective and objective data. I created and administered the questionnaire mainly from Naunton, Hughes, Hutchinson, and Waters. There is also a learning style inventory that I found relevant to this study to identify their learning style. (Appendix 2)

Key Findings:

- Motivation: They are extrinsically and instrumentally motivated. They need to pass the test in order to enter university or live abroad. The level of extrinsic motivation is higher than instrumental one.

- Learning style: They are mainly visual and auditory learners. The visual learner prefers to take notes and make pictures. The auditory learners prefer communication activities. They prefer to read their work aloud.

- Learners' preferences: They all prefer to improve IELTS receptive modules and learn strategies to help them answer the questions properly. This indicates that they have similar expectations.

2.2.2 Diagnostic Testing (DT): Harris and McCann (1994) mention that diagnostic tests are based on failure whereas almost all other tests are based on success. During the interview session, I noticed that they need to improve their receptive skills more than productive ones. Based on my observation and the NA results, which reveal the training gap in receptive skills, I chose past academic receptive modules of IELTS papers for their DT. The students were quite aware of the format and difficulty level of the tests so the tests had content and face validity. They took the tests in one session and in 1 hour and $40 \mathrm{~min}$. Since the scoring in receptive skills in IELTS is objective, the tests were considered reliable. (Appendix 3)

Key Findings:

The percentages here represent the correct answers given by students.

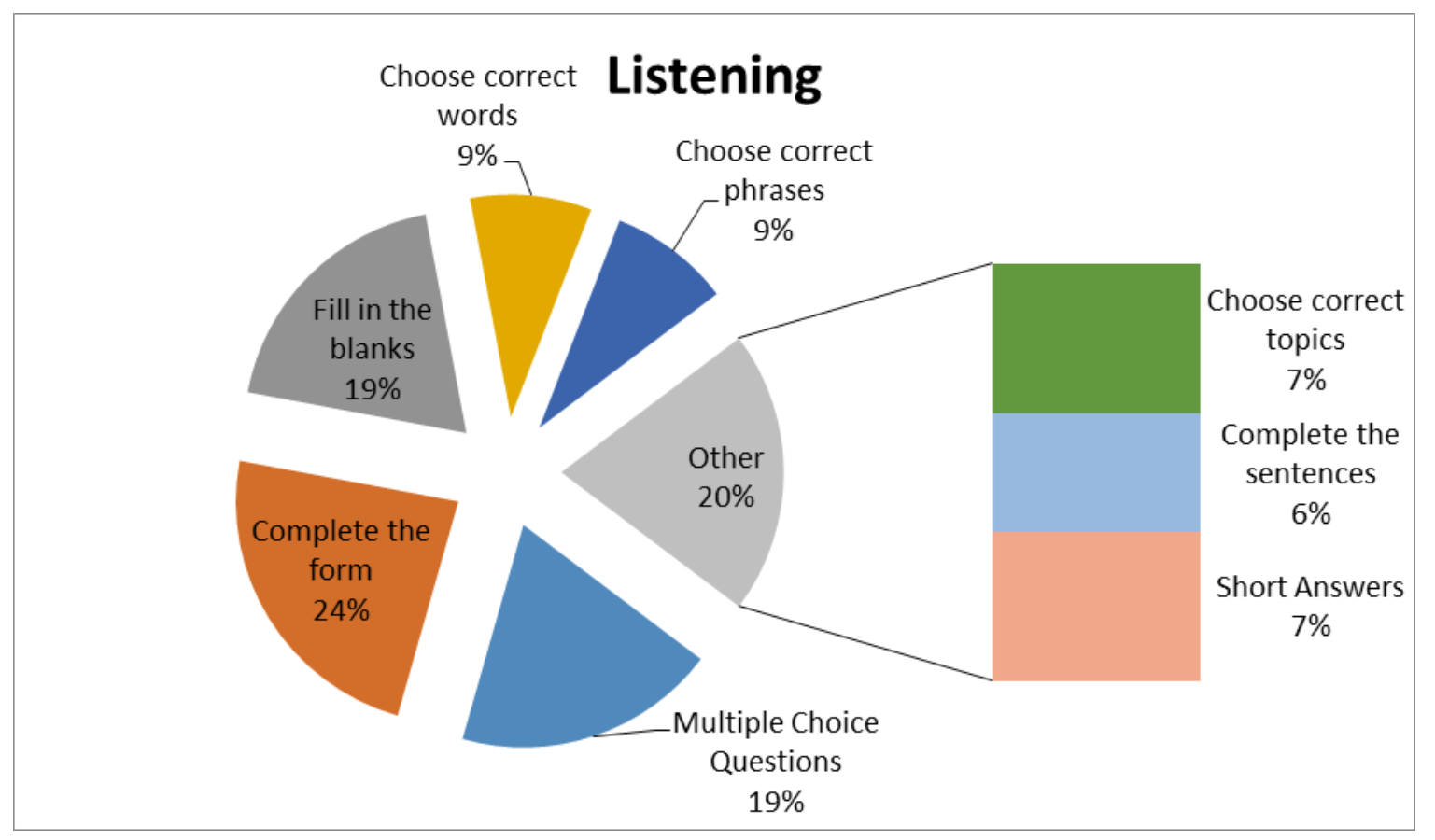

The students' weaknesses are in complete the sentences (6\%), choose the topics and short answers (7\%) and choose correct words and choose correct phrases (9\%). They block mainly on unknown vocabulary and pronunciation, especially in longer recordings. 


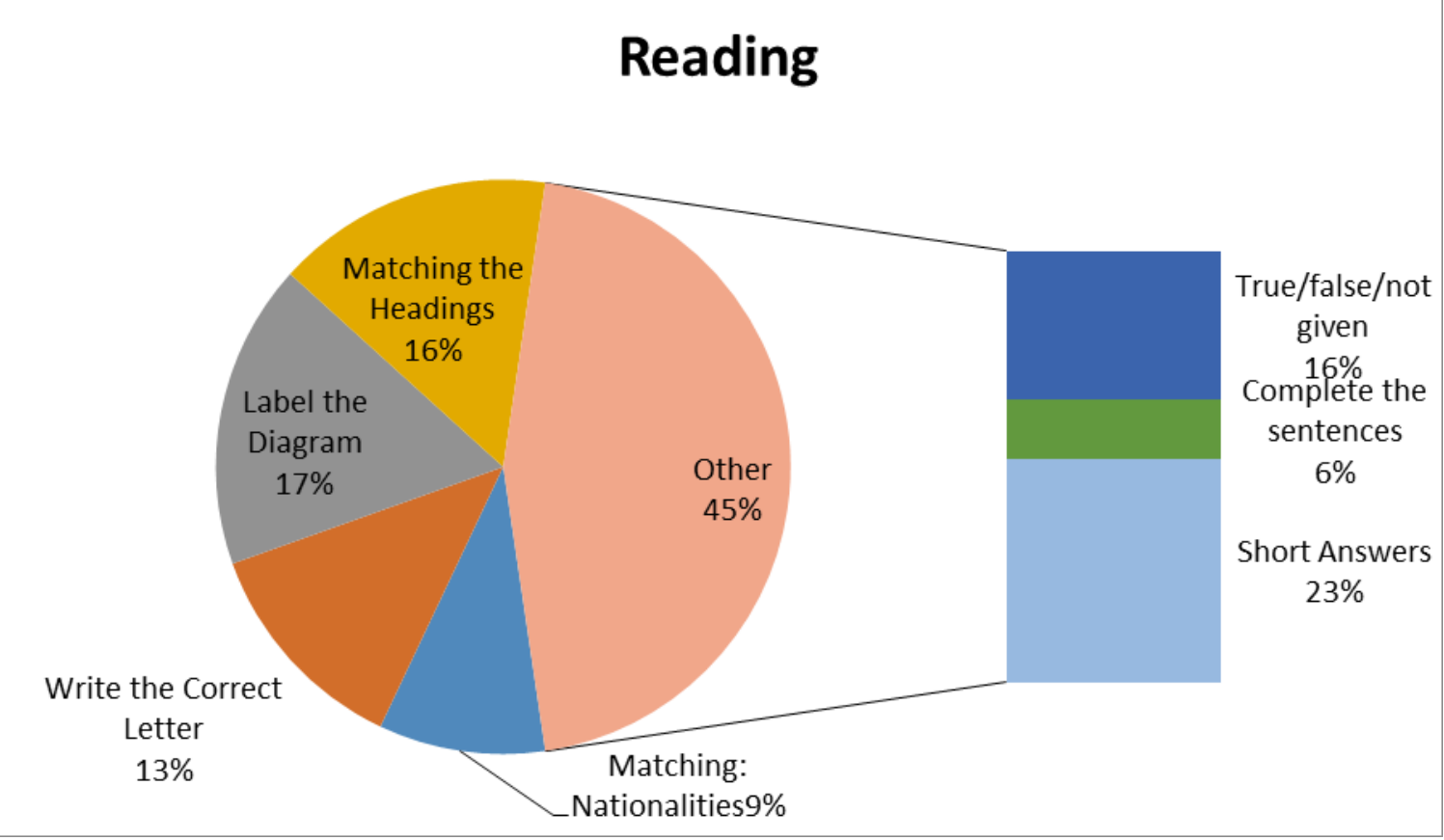

Their weaknesses are mostly in complete the sentences (6\%) and matching paragraphs (9\%). These results reveal that unknown vocabulary and lack of employing reading skills are their main weaknesses in Reading.

\subsection{Question Type Questionnaire and Interview}

This is a small group of learners and as Graves (2000) mentions, it is feasible to adapt different methods to collate data. In this case, the possibility of misinterpretation of the teacher's observation and students' actual needs would reduce. The main purpose of this questionnaire is to compare students' conception of their own weaknesses and strengths with the outcome of the diagnostic test. The results of the DT proved that students have an accurate understanding of their strengths and weaknesses in receptive modules of IELTS. They found complete the sentences, choose the topics and short answers, choose correct words, choose correct phrases problematic in Listening, and complete the sentences and matching paragraphs problematic in Reading (Appendix 4).

An informal interview was also done after the DT to discuss the problematic areas in the test. The questions were designed based on observation and the outcome of NA (Appendix 5).

Key Findings:

- Time management is an issue,

- They need to improve their IELTS vocabulary,

- They need to know how to approach different reading and listening questions,

- They expect a lot of homework and feedback individually after each test,

\subsection{Priorities for Learning and Course Design}

$\begin{array}{llll}\text { Area } & \text { They need to... } & \text { Based on } & \text { Evidence }\end{array}$

\begin{tabular}{|c|c|c|c|}
\hline Listening & $\begin{array}{l}\text { develop listening skills: listening for gist, specific } \\
\text { information etc. }\end{array}$ & DT & Appendix 3 \\
\hline Listening & $\begin{array}{l}\text { take notes of key words and numbers while } \\
\text { listening. }\end{array}$ & Observation & \\
\hline Listening & be exposed to different types of questions. & $\begin{array}{l}\text { NA, DT, } \\
\text { Interview, }\end{array}$ & Appendix $2,3,5$ \\
\hline Reading & improve their reading speed. & Interview & Appendix 5 \\
\hline Reading & develop reading skills: skimming, scanning etc. & $\begin{array}{l}\text { Question Type } \\
\text { Questionnaire, } \\
\text { Interview }\end{array}$ & Appendix 4,5 \\
\hline Reading & $\begin{array}{l}\text { infer the meaning of unfamiliar words from the } \\
\text { context and their own background knowledge. }\end{array}$ & Interview & Appendix 5 \\
\hline Vocabulary & improve their academic vocabulary. & $\begin{array}{l}\mathrm{NA}, \mathrm{DT}, \\
\text { Interview }\end{array}$ & Appendix 2., 3, 5 \\
\hline $\begin{array}{l}\text { Learner } \\
\text { Training }\end{array}$ & $\begin{array}{l}\text { focus on their individual learning preferences and } \\
\text { strategies. }\end{array}$ & NA & Appendix 2 \\
\hline
\end{tabular}




\section{Course Proposal}

\subsection{Goals and Objectives}

Graves (2000) says that goals are the main outcomes of a course and objectives spell out how these goals are supposed to be achieved. She also believes that objectives are in a hierarchical relationship to goals. Brown (1995) noted that the level of specificity is the main difference between goals and objectives. Goals are more general and objectives more specific. Nunan (1988) believes that the results of NA can be used to set goals and objectives. Stern (1992) has categorized goals in four groups: Cognitive, Proficiency, Affective and Transfer goals. The following goals are set based on the students' needs, wants, weaknesses, and Graves' (2000) framework.

a) Proficiency goal: By the end of the course, students will have developed effective receptive skills and will obtain score 6 in the receptive modules of IELTS.

b) Transfer goal: By the end of the course, students will have developed their interpersonal skills and learner strategies and will have a clear understating of how to continue to develop their receptive skills.

c) Affective goal: By the end of the course, students will have developed a positive attitude and confidence in their ability to approach IELTS.

Graves (2000) notes that a goal can be broken down into different objectives. By achieving the objectives then the goal will be reached. For this reason, there must be a relationship between objectives and goals. Richards (1990) identifies four different types of objectives: Behavioral, Skills-based, Content-based and Proficiency-based objectives. Based on the NA results, I have identified some lacks in micro-skills of listening and reading. The students need to develop their learning strategies and their positive attitude in order to approach the exam systematically. For this reason, I have chosen skills-based and behavioral objectives (Appendix 1).

\subsection{Syllabus Design}

Richards (2002) defines syllabus as a description of the contents, instructions of a course and the teaching order of each part. He believes syllabuses are designed based on various criteria such as grammatical items, vocabulary or language functions, and situations. There are different ways in which syllabuses are analyzed. One dimension of analysis is the synthetic/analytic dimension. Wilkins (1976) notes that an analytic syllabus is designed based on learners' needs.

Nunan (1988) categorizes syllabuses into two groups:

- Product-oriented: in which the focus is on the skills and knowledge that learners are supposed to obtain because of instruction.

- Process-oriented: in which the focus is on the learning experiences.

This syllabus is largely an analytic one, which lets students analyze the items of most use to them. On the other hand, although there are some product-oriented objectives in this syllabus like achieving academic vocabulary, it is primary process-oriented as the focus is mainly on learning strategies. I believe the students need to be exposed to a variety of texts and activities to improve their learning strategies. This can be achieved best through skills-based syllabus as Munby (1987) mentions. The goal of skills based syllable is to improve the learners' ability within specified skills using different micro-skills, language systems and activities rather than merely focusing on a particular form.

\subsection{Sequencing of Content}

Freeman (1998) says that language acquisition is not a linear and discrete process, but it is an organic and unpredictable one. Nunan's task continuity principle (1989) which is about the essential relationship between the completion of a prior activity as a prerequisite for succeeding one, is the major consideration in sequencing materials in this syllabus. Each lesson starts with a noticing activity to activate students' awareness of the lesson. The activities are appropriately sequenced to meet the needs of the students. For instance, in session 1, students are introduced to skimming and scanning followed by a short activity. They then in session 2 apply the techniques to do a reading activity and develop the use of reading skills. Another example of sequencing can be seen within session 6 in which the listening skill of prediction is introduced in one activity and practiced in another. I also utilized homework in session 2 to set the framework of the reading lesson in session 3.

\subsection{Teaching Approach and Materials}

A task-based teaching is utilized to create a beneficial backwash in the course by creating a balance between teaching and testing. The tasks and materials are also designed based on students' needs, preferences (Appendix 2) and IELTS content in order to help students develop their strategies, achieve the transfer goal and succeed in the exam. Materials are prepared based on course objectives, students' needs and motivation, difficulty level and content of IELTS. A variety of recordings and clear visual materials are also prepared to meet the needs of visual and auditory students. A range of past IELTS papers, published and self-made materials are prepared to respond to the students' needs of various topics and contexts and to familiarize them with the authentic texts and question types. In order to motivate the students, avoid burnout effect and to make a balance between receptive and productive components of the exam, a writing activity in session 5, some speaking activities in session 3,5,7,8,9, some grammar activities in session 4 and 7 and some pronunciation lessons in session 3 and 10 are also designed. Vocabulary activities in session 2, 3, 5, 8 and 9 are designed to boost the students' needs in academic vocabulary. A learner diary at the end of each session creates learner autonomy. The stages of each lesson are pre-task, task and post task. 


\section{Assessment and Evaluation}

Graves (2000) believes that assessment plays three major roles in course design: assessing needs, assessing students' learning, and evaluating the course. Ur (1991) draws a distinction between assessment (learners' performance) and evaluation (effectiveness of a syllabus). Brown (2001) says that assessment can be done in three ways: formal, informal and self-assessments. Graves (2000) reflects that assessment can be both formative and summative.

\subsection{Formative Assessment}

4.1.1 Formal: as Graves (2000) indicates, formative assessment takes place during the course and provides information about how well the students are progressing in the course, and allows the teacher to make future adjustments to the syllabus. She also reflects that assessing progress means to find what students have learned so far in the course and the best criteria for assessing a skill-based course is the goals and objectives of the course. For this reason and based on the students' positive approach towards tests (Appendix 5), the course objectives can be used as the assessment criteria for the students' progress. Since this is a short course, two formative tests are prepared:

\begin{tabular}{lllll}
\hline Test & Session & Content & Time (min) & Objective \\
\hline 1 & After 3 & Reading & 30 & $2,3,5$ \\
\hline 2 & After 6 & Reading/Listening & 45 & $2,3,4,5$ \\
\hline
\end{tabular}

Hughes (1989) believes that a test has content validity when its content constitutes a representative sample of the language skills and relevant structures. Baxter (1997) says face validity means the test should appear to test what it is supposed to test. The tests here test subskills/tasks previously worked on in class and are prepared from past IELTS tests in order to maximize the content and face validity. For example, formative test 1 tests students' understanding of skimming, scanning and reading for details by multiple choice and Yes/No/Not Given questions. All these skills are developed in sessions 1,2 and 3 .

Hughes (1989) reflects that if we intend to directly test the skills that we want to improve, then practice for the test should represent practice in those skills. The tests here test students' skills directly and expose them to actual exam papers in order to develop their exam skills.

All sub-skills of reading and listening are considered in the tests. As the tests are scored objectively, they are considered reliable. The tests reflect class work so they can create positive backwash. Some questions in test 1 are repeated in test 2 in order to create a link between them and assess students' progress in particular sub-skills: for example "Complete the sentences" in both tests.

4.1.2 Informal: Harris (1994) says that informal assessment is a continuous way of collecting information about students' performance without establishing the conditions of formal assessment. The time we have for informal assessment is limited, as we need to follow the aims of the lesson. For this reason, we should know exactly what we are going to assess informally. Harris (1994) believes that non-linguistic factors are also important elements in students' overall development. Students' attitude, cooperation, independence, creativity, and participation in different activities will be assessed through a formative class log (Appendix 6). The information obtained will reveal a clearer picture of the students' emerging needs. The linguistic factors will be assessed by class observation and assessment of their performance in different tasks.

\subsection{Self-assessment}

Harris and McCann (1994) say that self-assessment provides us with useful information about students' needs, feelings about their progress and the course in general. Two self- assessment tools will be used for self-assessment:

4.2.1 Learners' diaries: students are given a questionnaire after each activity to evaluate the activity. This will result in developing learner autonomy (Appendix 7).

4.2.2 Counseling: can-do statements against objectives will be used to focus on problematic areas individually which in turn results in better self-assessment.

\subsection{Summative Assessment}

Graves (2000) notes that summative assessment is done at the end of a course and provides information about the students' achievement and the overall effectiveness of the course. Based on the objectives and the work done during the course, a mock IELTS test is prepared to assess the students and course overall success.

\begin{tabular}{llll}
\hline Session & Content & Time $(\mathrm{min})$ & Objective \\
\hline After 10 & Listening/Reading & 45 & All \\
\hline
\end{tabular}

Harris and McCann (1994) note that a test is valid if it tests what we want them to test and nothing extra and it is reliable if it has consistent measures of students' performance. This summative test is valid and reliable as it measures the students' performance only in receptive skills. Harris and McCann (1994) also reflect that a test must not be too long in order to be practical. This test is practical as it takes $45 \mathrm{~min}$. The effectiveness of the course will be tested by assessing the success of the objectives. For doing so, the scores between the diagnostic and summative tests will be compared to find greater/fewer improvements in different areas of reading and listening. For example, if the scores in 
"Label the diagram" section of reading in the summative test is much greater that the same section in the diagnostic test, this indicates improvement in scanning and reading for details, which in turn proves the success of objective 3 .

\section{Evaluation}

Bachman (1990) defines evaluation as the systematic gathering of information in order to make decisions. Dickins and Garmaine (1993) note that evaluation is an essential part of a course and it is important mainly because it provides useful information for planning and managing the course. Students' performance in the tests and also their level of satisfaction with the course can be good criteria for course evaluation. The following tools will be used to evaluate the effectiveness of the course:

5.1 End-of-course Questionnaire: The students will be given a questionnaire about different aspects of the course to find about their level of satisfaction with the course (Appendix 8).

5.2 Comparing Tests Results: The results of DT, formative and summative tests (Appendix 9) will be compared. If students have progressed during the course this means that, the course has been effectively designed.

The results of the evaluation will be used to keep the effective aspects of the course and to change ineffective aspects in order to improve the course.

\section{Conclusion}

Based on the NA and DT outcome, the main objective of this course is to improve the students' receptive scores in IELTS. The course has been appropriately designed to meet this need.

The principles mentioned in part 1 have all been implemented in the course:

- Backwash Effect: In order to create beneficial backwash, the teaching methodologies and materials were prepared based on the students' interest and level and valid tests were designed for formative and summative assessments.

- Motivation: A variety of factors have been implanted in the course to sustain motivation such as motivating tasks and materials, feedback based on individual needs, counseling sessions and self-assessment tools.

- Student Autonomy: Student autonomy has been achieved through various tools such as learners' diaries, questionnaires, counseling sessions and exam and homework feedback sessions. Learner training lessons have been considered comprehensively throughout the course.

6.1 Benefits: Although the focus of the course is on receptive skills, students are able to improve their productive skills, grammar, vocabulary and learner training strategies, which are necessary for all modules of IELTS. Various assessment tools have been implemented to reassure the success of the course.

6.2 Limitations: Receptive skills are hard to measure; it could be hard to judge exactly how well students have improved. This is a short course and has been designed to improve students' receptive skills mainly through topdown strategies. As most IELTS materials are prepared for intermediate and upper-intermediate, grading materials for low-intermediate students is rather challenging. Due to the intensive nature of the course, if one student is absent for one session, he/she might lose some important and necessary lessons which may affect their learning, and this might also affect the pair/group work activities as there are only four students in class.

\section{References}

Bachman, L. (1990). Fundamental Considerations in Language Testing. Oxford; New York: OUP.

Baxter, A. (1997). Evaluating your Students. UK: Richmond Publishing.

Brown, D. (1995). Elements of language curriculum, A systematic approach to program development. Boston; Heinle \& Heinle.

Brown, D. (2001). Teaching by Principles. Longman; New York: Pearson Education.

Burgess, S and Head, K. (2005). How to Teach for Exams. UK: Pearson Education.

Dickins, P and Garmaine, K. (1993). Evaluation. Oxford; New York: OUP.

Freeman, D. (1998). Doing teacher research: From inquiry to understanding. Boston: Heinle \& Heinle.

Graves, K. (2000). Designing Language Courses: A Guide for Teachers. Boston; Heinle \& Heinle.

Harmer, J. (2007). How to Teach English. Longman; UK: Pearson Education.

Harris, M and McCann, P. (1994). Assessment, Macmillan; Oxford: Macmillan Publishers Ltd.

Howatt, A. (1984). A history of English language teaching. Oxford: Oxford University Press.

Hughes, A. (1989). Testing for Language teachers. Cambridge; UK: CUP.

Hutchinson, T. \& Waters, A. (1987). English for Specific Purposes. Cambridge: CUP.

May, P. (1996). Exam Classes. Oxford: OUP.

McEwan, N. ( 1995). Educational Accountability in Alberta. Canadian Journal of Education. 20.27-44

Munby, J. (1987). Communicative Syllabus Design Cambridge: CUP. 
Naunton, J. and Hughes, J. (1997). Online Instruction Center, Teaching for the FCE in English, retrieved on 20.03.2013 from

https://eltadvantage.ed2go.com/Classroom/Lessons.aspx?lesson=1\&chpt=1\&classroom=Fwhl7SbG1clEVE9BkBFbdT1 q2qV3awzEB2ZRBM0mHMk\%3d

Nunan, D. (1988). Syllabus Design. Oxford; New York: OUP.

Nunan, D. (1989). Designing Tasks for the Communicative Classroom. Cambridge: CUP.

Oxford, R. (1990). Language Learning Strategies: What Every Teacher Should Know. USA: Heinle \& Heinle Publication.

Prodmorou, L. (1995). the backwash effect: from testing to teaching. ELTJ Volume 49/1, 1995,

OUP.

Richards, J. C. (1990). The Language Teaching Matrix. Cambridge: CUP.

Richards, J. C. and Schmidt, R. (2002). Longman Dictionary of Language Teaching and Applied Linguistics. ( $)$ Pearson Education Limited (Third Edition).

Stern, H. (1992). Issues and Options in Language Teaching. Oxford: OUP.

Tickoo, M. (1988). Michael West in India: a centenary salute. English Language Teaching Journal, 42, 4, 294-300.

Ur, P. (1991). A course in language teaching. Cambridge: New York: CUP.

Wilkins, D. (1976). Notional Syllabus. London: Oxford University Press.

\section{Appendix 1}

Objectives:

\begin{tabular}{|c|c|c|c|}
\hline & By the end of the course, students will be better able to... & Link to Goal & Link to Priority \\
\hline 1 & $\begin{array}{l}\text { understand the meaning of unknown terms from the context and have } \\
\text { practiced different strategies to infer meaning from the context in IELTS. }\end{array}$ & $\mathrm{Ga}, \mathrm{Gb}$ & P6, P8 \\
\hline 2 & $\begin{array}{l}\text { respond to various types of receptive exam questions in different contexts } \\
\text { in IELTS like fill in the blanks, true/false and matching questions more } \\
\text { confidently. }\end{array}$ & $\mathrm{Ga}, \mathrm{Gb}, \mathrm{Gc}$ & P3 \\
\hline 3 & $\begin{array}{l}\text { approach reading questions in IELTS systematically by using various } \\
\text { reading strategies like skimming, scanning or reading for specific } \\
\text { information. }\end{array}$ & $\mathrm{Ga}, \mathrm{Gb}$ & P5 \\
\hline 4 & $\begin{array}{l}\text { approach listening questions in IELTS systematically using various } \\
\text { listening strategies like listening for gist, for specific information and note } \\
\text { taking. }\end{array}$ & $\mathrm{Ga}, \mathrm{Gb}$ & $\mathrm{P} 1, \mathrm{P} 2$ \\
\hline 5 & $\begin{array}{l}\text { improve their reading speed in IELTS by using different reading strategies } \\
\text { like skimming and scanning. }\end{array}$ & $\mathrm{Ga}, \mathrm{Gb}$ & $\mathrm{P} 4$ \\
\hline 6 & expand their academic lexis in different contexts for IELTS. & $\mathrm{Ga}$ & P7 \\
\hline 7 & $\begin{array}{l}\text { understand their interpersonal learning strategies and styles through } \\
\text { exposure to different tasks. }\end{array}$ & $\mathrm{Gb}$ & P8 \\
\hline
\end{tabular}

\section{Appendix 2:}

Needs Analysis Questionnaires

We would like to know more about you in order to plan an effective course. There are three sections in this questionnaire. Please read the questions carefully and answer them appropriately. Your teacher is ready to answer your questions if you have any.

Name:

Age:

Nationality:

Section one: (Tick answers)

1. How long have you been studying English?
a. Less than one year
b. 1-2years
c. 3-5years
d. More than 5 years

2. How often do you use English out of English class?
a. Always
b. Usually
c. Sometimes
d. Never 
3. What are your reasons for taking this IELS course?
a. For personal interest
b. To gain a professional qualification for work
c. To gain entry into university
d. I've been told to take it

Other reason

4. How often do you write in English?
a. Always
b. Usually
c. Sometimes
d. Never

5. How often do you read in English?
a. Always
b. Usually
c. Sometimes
d. Never

6. How often do you listen to English music or watch English movies?
a. Always
b. Usually
c. Sometimes
d. Never

7. How often do you speak in English?
a. Always
b. Usually
c. Sometimes
d. Never

8. The IELTS exam has the following four modules. Number them from 1 to 4 in order of your ability:

$1=\mathrm{I}$ think this is my strongest area

$4=\mathrm{I}$ think this is my weakest area

\begin{tabular}{|l|l|l|l|l|}
\hline & 1 & 2 & 3 & 4 \\
\hline Listening & & & & \\
\hline Reading & & & & \\
\hline Writing & & & & \\
\hline Speaking & & & & \\
\hline
\end{tabular}

9. Why are you learning English apart from taking IELTS examination?
a. To find a good job
b. To travel to foreign countries
c. To enjoy watching movies
d. To communicate with others online
e. To search online
f. To continue my studies in an English university
g. To live in a foreign country
h. Others

\section{Section two:}

Part 1: What do you expect from an IELTS preparation course? Rate your opinion. I attend this IELTS preparation course:

1. to improve my grammar for IELTS
a. strongly disagree
b. disagree
c. don't know
d. agree
e. strongly agree

2. to improve my writing for IELTS
a. strongly disagree
b. disagree
c. don't know
d. agree
e. strongly agree

3. to improve my speaking for IELTS
a. strongly disagree
b. Disagree
c. don't know
d. agree
e. strongly agree

4. to improve my reading for IELTS
a. strongly disagree
b. disagree
c. don't know
d. agree
e. strongly agree 
5. to improve my listening for IELTS
a. strongly disagree
b. disagree
c. don't know
d. agree
e. strongly agree

6. to improve my vocabulary for IELTS
a. strongly disagree
b. disagree
c. don't know
d. agree
e. strongly agree

7. to improve exam skills
a. strongly disagree
b. disagree
c. don't know
d. agree
e. strongly agree

8. to improve my pronunciation
a. strongly disagree
b. disagree
c. don't know
d. agree
e. strongly agree

9. to learn academic writing
a. strongly disagree
b. disagree
c. don't know
d. agree
e. strongly agree

10. to learn about the format of IELTS exam
a. strongly disagree
b. disagree
c. don't know
d. agree
e. strongly agree

11. to learn how to answer each module of IELTS exam
a. strongly disagree
b. disagree
c. don't know
d. agree
e. strongly agree

12. to learn how to answer the question under time pressure
a. strongly disagree
b. disagree
c. don't know
d. agree
e. strongly agree

13. my teacher to correct my mistakes
a. strongly disagree
b. disagree
c. don't know
d. agree
e. strongly agree

14. my teacher to prepare sample IELTS questions for me
a. strongly disagree
b. disagree
c. don't know
d. agree
e. strongly agree

Part 2: Topics of interest

Which topics would you like to discuss and work in class? (You can choose more than one)

1. politics

2. social life

3. technology

4. business

5. science

6. jobs

7. family

8. education

9. cultures

10. music

11. others:

\section{Section three:}

Learning style

Adapted from: http://www.sgibson.k12.in.us/gshs_new/Gidcumb/Assignemt_1_Learning_Style_Inventroy.pdf

Learning Style Inventory

To better understand how you prefer to learn and process information, place a tick in the appropriate space after each statement below. This 24- item survey is not timed. Respond to each statement as honestly as you can.

\begin{tabular}{|c|c|c|c|}
\hline \multirow{2}{*}{$\begin{array}{l}\text { 1. I can remember best about a subject by listening to a lecture that includes } \\
\text { information, explanations, and discussions. }\end{array}$} & Often & Sometimes & Seldom \\
\hline & & & \\
\hline $\begin{array}{l}\text { 2. I prefer to see information written on a chalkboard and supplemented b } \\
\text { visual aids and assigned readings. }\end{array}$ & & & \\
\hline 3. I like to write things down or to take notes for visual review. & & & \\
\hline 4. I prefer to use posters, models, or actual practice and other activities in & & & \\
\hline
\end{tabular}




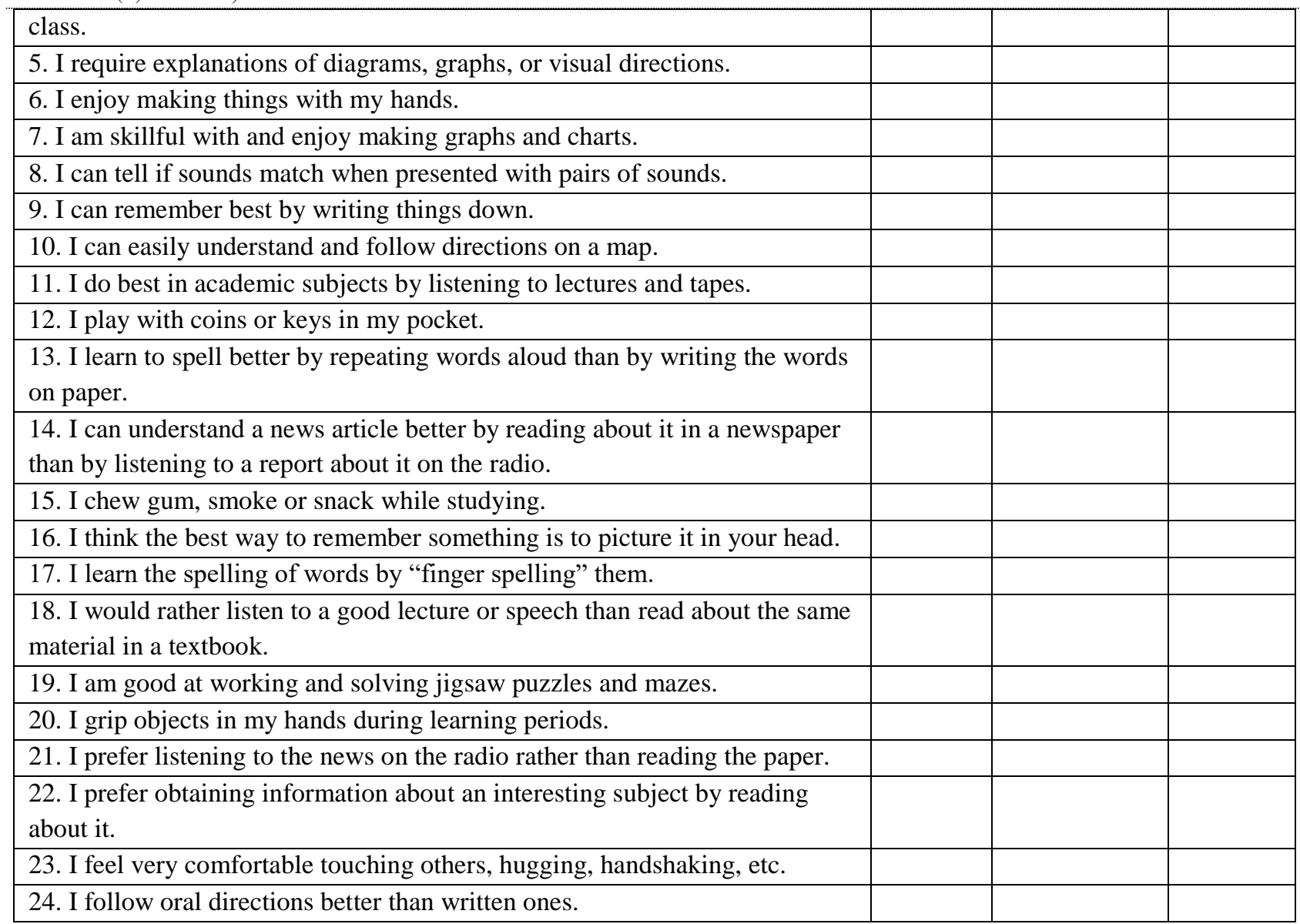

Inventory Scoring Procedures:

Directions: Place the point value on the line next to the corresponding item below. Add the points in each column to obtain the preference score under each heading.

OFTEN $=5$ points SOMETIMES $=3$ points SELDOM $=1$ points

\begin{tabular}{|l|l|l|l|l|l|}
\hline & VISUAL & & AUDITORY & & TACTILE \\
\hline No. & PTS. & No. & PTS. & No. & PTS. \\
\hline 2 & & 1 & & 4 & \\
\hline 3 & & 5 & & 6 & \\
\hline 7 & & 8 & & 9 & \\
\hline 10 & & 11 & & 12 & \\
\hline 14 & & 13 & & 15 & \\
\hline 16 & & 18 & & 17 & \\
\hline 19 & & 21 & & 20 & \\
\hline 22 & & 24 & & 23 & \\
\hline VPS $=$ & & APS $=$ & & TPS $=$ & \\
\hline VPS & Visual & APS & $\begin{array}{l}\text { Audio } \\
\text { Preference }\end{array}$ & TPS & $\begin{array}{l}\text { Tactile } \\
\text { Preference }\end{array}$ \\
\hline
\end{tabular}

Total the score for each section. A score of 21 points or more in a modality indicates strength in that area. The highest of the 3 scores indicates the most efficient method of information intake. The second highest score indicates the modality, which boosts the primary strength. For example, a score of 23 in visual modality indicates a strong visual learner... 
Appendix 3:

Diagnostic Test

Listening:

\begin{tabular}{|c|c|c|c|c|c|c|}
\hline & Question Type & $\begin{array}{c}\text { No. of } \\
\text { Correct } \\
\text { Answers - } \\
\text { Student } 1\end{array}$ & $\begin{array}{c}\text { No. of } \\
\text { Correct } \\
\text { Answers - } \\
\text { Student } 2\end{array}$ & $\begin{array}{c}\text { No. of } \\
\text { Correct } \\
\text { Answers - } \\
\text { Student } 3\end{array}$ & $\begin{array}{c}\text { No. of } \\
\text { Correct } \\
\text { Answers - } \\
\text { Student } 4\end{array}$ & $\begin{array}{c}\text { Total } \\
\text { Questions }\end{array}$ \\
\hline \multirow[t]{2}{*}{ Section 1} & Multiple Choice Questions & & & & & \\
\hline & Complete the form & & & & & \\
\hline \multirow[t]{3}{*}{ Section 2} & Fill in the blanks & & & & & \\
\hline & Choose correct words & & & & & \\
\hline & Choose correct phrases & & & & & \\
\hline \multirow[t]{3}{*}{ Section 3} & Multiple Choice Questions & & & & & \\
\hline & Choose correct topics & & & & & \\
\hline & Complete sentences & & & & & \\
\hline Section 4 & Short Answers (one word) & & & & & \\
\hline Total & & & & & & \\
\hline
\end{tabular}

Reading:

\begin{tabular}{|l|l|l|l|l|l|l|}
\hline & \multicolumn{1}{|c|}{ Question Type } & $\begin{array}{c}\text { No. of } \\
\text { Correct } \\
\text { Answers - } \\
\text { Student 1 }\end{array}$ & $\begin{array}{c}\text { No. of } \\
\text { Correct } \\
\text { Answers - } \\
\text { Student 2 }\end{array}$ & $\begin{array}{c}\text { No. of } \\
\text { Correct } \\
\text { Answers - } \\
\text { Student 3 }\end{array}$ & $\begin{array}{c}\text { No. of } \\
\text { Correct } \\
\text { Answers - } \\
\text { Student 4 }\end{array}$ & $\begin{array}{c}\text { Total } \\
\text { Questions }\end{array}$ \\
\hline Section 1 & Write the correct Letter & & & & & \\
\hline & Matching: Nationalities & & & & & \\
\hline Section 2 & Label the Diagram & & & & & \\
\hline & Matching the Headings & & & & & \\
\hline Section 3 & Complete the sentences & & & & & \\
\hline & Short Answers (three words) & & & & & \\
\hline Total & & & & & & \\
\hline
\end{tabular}

Scoring:

If you score ...

\begin{tabular}{|c|c|c|}
\hline $0-14$ & $15-29$ & $30-40$ \\
\hline $\begin{array}{l}\text { You are unlikely to get an } \\
\text { acceptable score under examination } \\
\text { conditions and we recommend that } \\
\text { you spend a lot of time improving } \\
\text { your English before you take IELTS. }\end{array}$ & $\begin{array}{l}\text { You may get an acceptable score } \\
\text { under examination conditions but we } \\
\text { recommend that you think about } \\
\text { having more practice or lessons } \\
\text { before you take IELTS. }\end{array}$ & $\begin{array}{l}\text { You are likely to get an acceptable } \\
\text { score under examination conditions } \\
\text { but remember that different } \\
\text { institutions will find different scores } \\
\text { acceptable. }\end{array}$ \\
\hline
\end{tabular}

Cambridge IELTS 8 Student's Book with Answers (2011:152) Official Examination Papers from University of Cambridge ESOL Examinations

\section{Appendix 4:}

Question Type Questionnaire

Taking into account the test you have just taken, rate your ability in different types of Listening and Reading questions based on the following scale:
1. Very easy
2. Easy
3. Average
4. Difficult
5. Very difficult

Listening questions:

\begin{tabular}{|c|c|c|c|c|c|}
\hline & 1 & 2 & 3 & 4 & 5 \\
\hline Complete the form & & & & & \\
\hline Fill in the blanks & & & & & \\
\hline Choose correct words & & & & & \\
\hline Choose correct phrases & & & & & \\
\hline
\end{tabular}




\begin{tabular}{|l|l|l|l|l|l|}
\hline Multiple Choice Questions & & & & \\
\hline Choose correct topics & & & & & \\
\hline Complete sentences & & & & & \\
\hline Short Answers (one word) & & & & & \\
\hline
\end{tabular}

Reading questions:

\begin{tabular}{|c|c|c|c|c|c|}
\hline & 1 & 2 & 3 & 4 & 5 \\
\hline \multicolumn{6}{|l|}{ Matching Paragraphs } \\
\hline \multicolumn{6}{|l|}{ Write the Correct Letter } \\
\hline \multicolumn{6}{|l|}{ Label the Diagram } \\
\hline \multicolumn{6}{|l|}{ Matching the Headings } \\
\hline \multicolumn{6}{|l|}{ True/false/not given } \\
\hline \multicolumn{6}{|l|}{ Complete the sentences } \\
\hline Short Answers (three words) & & & & & \\
\hline
\end{tabular}

\section{Appendix 5:}

Interview Questions:

1. What do you think are the most important skills that you need to practice for IELTS?

2. What do you want to learn in this course? Do you think your IELTS results would depend on your teachers or yourselves?

3. What do you think are some challenges you may face when studying English? How do you solve these problems?

4. Are you quite clear about the format of the IELTS test? How do you approach the reading module of the test?

5. How do you approach the listening module of the test?

6. What do you expect from your teacher during the course?

7. How much homework are you ready to do?

8. What do think about the test during the course?

\section{Appendix 6}

Class log

Scale 1: :)

Scale 5: :)

\begin{tabular}{|c|c|c|c|c|c|c|c|c|c|c|c|}
\hline Factors $\quad \downarrow \quad /$ & Sessions $\rightarrow$ & 1 & 2 & 3 & 4 & 5 & 6 & 7 & 8 & 9 & 10 \\
\hline Attitude toward learning & (scale of 1 to 5 ) & & & & & & & & & & \\
\hline Cooperativeness & (scale of 1 to 5$)$ & & & & & & & & & & \\
\hline Creativity & (scale of 1 to 5 ) & & & & & & & & & & \\
\hline Independence & (scale of 1 to 5 ) & & & & & & & & & & \\
\hline Presentation skills & (scale of 1 to 5 ) & & & & & & & & & & \\
\hline Attendance & (scale of 1 to 5$)$ & & & & & & & & & & \\
\hline Motivation & (scale of 1 to 5 ) & & & & & & & & & & \\
\hline Ability to accomplish tasks & (scale of 1 to 5 ) & & & & & & & & & & \\
\hline Ability to follow instructions & (scale of 1 to 5 ) & & & & & & & & & & \\
\hline Homework & (scale of 1 to 5 ) & & & & & & & & & & \\
\hline
\end{tabular}

\section{Appendix 7}

Self-assessment tool

Name:.

Date.

Class.

A. Answer the following questions about this session:

1. What activities did you find most useful? Why?

2. What activities did you find least useful? Why?

3. What would you suggest to improve activities? 
B. Assess your understanding of this lesson.

\begin{tabular}{|l|l|l|}
\hline tick & & Self-assessment \\
\hline & $100 \%$ & I understood absolutely everything \\
\hline & $90 \%$ & I understood nearly everything. I only missed a few words. \\
\hline & $75 \%$ & I understood most of it, but I did not understand a few sentences. \\
\hline & $50 \%$ & I understood the situation quite well, though I missed many of the details. \\
\hline & $35 \%$ & I got a general idea, but at times, I got a bit lost. \\
\hline & $20 \%$ & I could understand what it was about more or less. \\
\hline & $10 \%$ & I understood a few words here or there. \\
\hline & $0 \%$ & I did not understand a single word. \\
\hline
\end{tabular}

C. Did you manage to complete the tasks? Yes No

Adapted from Michael Harris and Paul McCann, Assessment (1994:76)

\section{Appendix 8}

End of course evaluation

Mark each of the following statements concerning evaluation on a scale of 5 from disagree to agree.

A. The course:

1. The content of the course was appropriate to my needs.
disagree
2
5 agree

4

2. The skills taught in the course were appropriate to my needs. $\begin{array}{lllllll}\text { disagree } & 1 & 2 & 3 & 4 & 5 & \text { agree }\end{array}$

3. There were no cultural misunderstanding. $\begin{array}{lllllll}\text { disagree } & 1 & 2 & 3 & 4 & 5 & \text { agree }\end{array}$

4. All instructions were clear. $\begin{array}{lllllll}\text { disagree } & 1 & 2 & 3 & 4 & 5 & \text { agree }\end{array}$

5. Materials and activities were appropriate. $\begin{array}{lllllll}\text { disagree } & 1 & 2 & 3 & 4 & 5 & \text { agree }\end{array}$

6. The class atmosphere was positive. $\begin{array}{lllllll}\text { disagree } & 1 & 2 & 3 & 4 & 5 & \text { agree }\end{array}$

7. The pacing of lessons was appropriate. $\begin{array}{lllllll}\text { disagree } & 1 & 2 & 3 & 4 & 5 & \text { agree }\end{array}$

8. There was enough variety in the lessons. $\begin{array}{lllllll}\text { disagree } & 1 & 2 & 3 & 4 & 5 & \text { agree }\end{array}$

9. Error correction and feedback were appropriate. $\begin{array}{lllllll}\text { disagree } & 1 & 2 & 3 & 4 & 5 & \text { agree }\end{array}$

B. Grading:

1. My overall understanding of the class assessment plan clear from the beginning of the course. $\begin{array}{lllllll}\text { disagree } & 1 & 2 & 3 & 4 & 5 & \text { agree }\end{array}$

2. The grades that received assessed my work fairly. $\begin{array}{lllllll}\text { disagree } & 1 & 2 & 3 & 4 & 5 & \text { agree }\end{array}$

3. I understand my teacher's method of grading my work. $\begin{array}{lllllll}\text { disagree } & 1 & 2 & 3 & 4 & 5 & \text { agree }\end{array}$

C. Teaching:

1. The teacher taught us what we needed most.

$$
\begin{array}{lllllll}
\text { disagree } & 1 & 2 & 3 & 4 & 5 & \text { agree }
\end{array}
$$

2. The teacher was well prepared for class.

$$
\begin{array}{lllllll}
\text { disagree } & 1 & 2 & 3 & 4 & 5 & \text { agree }
\end{array}
$$

3. The teacher treated me fairly.

$$
\begin{array}{lllllll}
\text { disagree } & 1 & 2 & 3 & 4 & 5 & \text { agree }
\end{array}
$$

4. General class management was good.

$\begin{array}{lllllll}\text { disagree } & 1 & 2 & 3 & 4 & 5 & \text { agree }\end{array}$

5. The teacher was responsive to my needs. disagree
$23 \quad 4$
5 agree

D. Self-assessment:

1. I tried to improve my vocabulary skills by using a monolingual dictionary.

$$
\begin{array}{lllllll}
\text { disagree } & 1 & 2 & 3 & 4 & 5 & \text { agree }
\end{array}
$$

2. I tried to improve my skills by keeping a record of my mistakes in a notebook. $\begin{array}{lllllll}\text { disagree } & 1 & 2 & 3 & 4 & 5 & \text { agree }\end{array}$

3. I carefully prepared a portfolio of my work. $\begin{array}{lllllll}\text { disagree } & 1 & 2 & 3 & 4 & 5 & \text { agree }\end{array}$

4. I ask my teacher for extra resources.

$$
\begin{array}{lllllll}
\text { disagree } & 1 & 2 & 3 & 4 & 5 & \text { agree }
\end{array}
$$

Adapted from Kathleen Graves (2000:295) Designing Language Courses: A Guide for Teachers 
Appendix 9

Evaluation - comparing test results

Reading

\begin{tabular}{|l|l|l|l|l|l|l|}
\hline Question type $\downarrow$ & DT & $\begin{array}{c}\text { Formative } \\
\text { test 1 }\end{array}$ & $\begin{array}{c}\text { Formative } \\
\text { test 2 }\end{array}$ & $\begin{array}{c}\text { Summative } \\
\text { test }\end{array}$ & Successful & Unsuccessful \\
\hline True/False/Not Given & & & & & & \\
\hline Label the diagram/Summary & & & & & & \\
\hline $\begin{array}{l}\text { Write the correct } \\
\text { letter/Heading }\end{array}$ & & & & & & \\
\hline Short answers & & & & & & \\
\hline Complete the sentences & & & & & & \\
\hline
\end{tabular}

Listening

\begin{tabular}{|l|l|l|l|l|l|l|}
\hline Question type $\downarrow$ & DT & $\begin{array}{c}\text { Formative } \\
\text { test 1 }\end{array}$ & $\begin{array}{c}\text { Formative } \\
\text { test 2 }\end{array}$ & $\begin{array}{c}\text { Summative } \\
\text { test }\end{array}$ & Successful & Unsuccessful \\
\hline Short answers & & & & & & \\
\hline Complete the form & & & & & & \\
\hline Multiple choice & & & & & & \\
\hline Complete sentences & & & & & & \\
\hline
\end{tabular}

